\title{
NEW DATA ON THE WINTERING AND SEDENTARY LIFE OF THE EUROPEAN TURTLE DOVE STREPTOPELIA TURTUR IN THE ALGERIAN NORTHERN SAHARA
}

\author{
Abdelwahab Chedad ${ }^{1,2 *}$, Djamel Bendjoudi ${ }^{3}$, Omar Guezoul ${ }^{2,4}$ \\ ${ }^{1}$ University Kasdi Merbah, Department of Biological Sciences, Ouargla, Algeria, \\ ${ }^{2}$ Laboratory of Saharan Bio-ressources: Preservation and Valorisation, Ouargla, Algeria, \\ ${ }^{3}$ University of Blida, Faculty of sciences of the nature and of the life, \\ Laboratory of Biotechnology, Environment and Health, Algeria \\ ${ }^{4}$ University Kasdi Merbah, Department of Agricultural Sciences, \\ Faculty of Nature Sciences and Life, Ouargla, Algeria
}

\begin{abstract}
The European Turtle Dove (Streptopelia turtur) is a summer-migrant pigeon fancier that can be found all over Algeria, especially in forests, orchards, gardens, palm groves, oases and around natural or artificial water bodies, but with a difference in its distribution. This paper provides new data on the wintering and sedentary life of Streptopelia turtur in the Algerian Northern Sahara. Data from several stations were recorded between 2018 and 2020. In Ghardaïa, where the summering period is spread over 8 months from March to October, the number of couples counted varied between 0.03 and 4.5 per hectare between 2018 and 2019. In Adrar, the Streptopelia turtur is considered a sedentary species. In Timimoun, it winters in gardens, palm groves and oases; during the breeding period, the number of couples recorded varied between 3 and 6.13 per hectare in 2019 and 2020 respectively. In the old Timimoun palm grove the number of couples in 2019 was 2.5 and 2.25 couples in 2020. On the other hand, during the wintering period, the density reached 10.33 couples/hectare in Timimoun in 2019/2020 and only 2.33 couples/hectare in the old palm grove. During cold season, the Streptopelia turtur partially leaves the palm groves and oases and prefers to winter in the towns around the gardens by frequenting restaurants and public markets where trophic resources are available. In the region of Ghardaïa, breeding begins just after the arrival of the species (March to April). But for the Adrar and Timimoun regions, breeding is early, with parade and nest building beginning in late January and the first broods being recorded in early February. So far, two subspecies have probably been identified: S. t. arenicola is the subspecies which breeds in Ghardaïa, Timimoun and Adrar and S. t. hoggara is the resident breeder subspecies which breeds in Timimoun and Adrar.
\end{abstract}

Keywords: Sahara, sedentarization, Streptopelia turtur, wintering.

\section{INTRODUCTION}

The Algerian Sahara spreads over nearly 2 million $\mathrm{km}^{2}$ corresponding to about $85 \%$ of the territory (Mediouni, 1997). Its climate is characterized in particular by the scarcity and irregularity of rainfall. In addition, thermal variations are particularly significant between day and night and between months (Doumandji and Doumandji-Mitiche, 1994). The Algerian Sahara is home to a very particular floristic and faunistic diversity (Chehma, 2006). The European Turtle Dove 
(Streptopelia turtur) is a migratory bird, and its nesting and wintering sites are well separated geographically (Ash, 1977; Gonnisen, 1986; Rouxel, 2000; Boutin, 2001; Brahmia, 2015). This pigeon species is present throughout Europe, from the Canary Islands in the west to the Urals in the east, but is totally absent in Scandinavia. The Streptopelia turtur has also been reported in western North Africa (Morocco, Algeria, and Tunisia) and Asia Minor (Cuisin and Doppia, 1992). Four subspecies (S. t. turtur, S. t. rufescens or isabelina, S. t. hoggara and $S$. t. arenicola) have been identified (Cramp, 1985; Morel, 1985; Veiga, 1998). In 2015, it was classified as a vulnerable species and included in the IUCN Red List of Threatened Species. The Streptopelia turtur is omnipresent on the whole Algerian territory. It is a summer-migrant breeder species throughout the northern part of the region, and resident almost everywhere in the Hoggar region. The subspecies $S$. t. arenicola nests in many woodland habitats from north to south, in the oases at Ouargla, El-Goléa and sometimes at Béni Abbés. However, it seems that it is not breeding at high altitude since its geographical distribution is limited to the piedmont of Kabylia. The subspecies $S$. $t$. hoggara breeds at Hoggar, Tibesti, Tassili and can be observed in Timimoun (Heim de balsac and Mayaud, 1962a; Heinzel et al., 1985; Isenmann and Moali, 2000; Boukhemza et al., 2008). Overall, subspecies $S$. $t$. isabellina and S. t. hoggara are considered to be quasi-sedentary (Ash, 1977 (loc. cit.)); Gonnisen, 1986 (loc. cit.); Rouxel, 2000 (loc. cit.); Boutin, 2001 (loc. cit.)).Several Algerian ornithologists have studied the Streptopelia turtur such as Isenmann and Moali (2000) (loc. cit.); Boukhemza et al. (2008) (loc. cit.); Merabet (2010); Belabed et al. (2012); Yahiaoui et al. (2014); Absi et al. (2015); Brahmia et al. (2015), Kafi et al. (2015a) However, no quantitative study on the wintering and sedentary life of this species has been carried out so far. This study aims to expand the current data on Streptopelia turtur, particularly in the Saharan regions. In addition, the analysis aims to provide more precise information on arrival and departure dates in the Ghardaiia region during the summering period across several ecosystems in order to determine the preferred habitats of this species. Furthermore, the study seeks to quantify the cases of wintering in the region of Timimoun (Adrar) and to delimit the wintering area with a confirmation of the sedentarization of the species in the Timimoun and Adrar regions.

\section{MATERIALS AND METHODS}

Two regions, Ghardaïa and Adrar, were selected for this case study. During a three-year period (march 2018 to march 2020). The first region, Ghardaïa, is located in the central part of northern Sahara and the second, Adrar, is located in the western part of northern Sahara (Heim de Balsac and Mayaud, 1962b). Both regions are part of the Saharan bioclimatic stage with a very low and irregular rainfall rate.

The Ghardaiia region is represented by three different sites:

(i) Kef Doukhane, is a permanent artificial wetland, located north of Ghardaïa. It was created recently, after the creation of the El Atteuf wastewater treatment plant. The area covers 550 ha (32²5'44.40"; 352'49.14") and the dominant plant species are: Nicotiana glauca, Phragmites australis and Typha angustifolia. (ii) The Noumérate green zone is a peri-urban environment located north of Ghardaïa and contains several forest plant species such as: Casuarina equisetifolia, Eucalyptus sp. and Schinus molle as well as agro-forestry plant species (Ceratonia siliqua, Olea sp., Acacia sp.). This station extends over 40 ha $\left(32^{\circ} 23^{\prime} 43.26^{\prime \prime} \mathrm{N} ; 3^{\circ} 46^{\prime} 3.59^{\prime \prime} \mathrm{E}\right)$. (iii) The new palm grove El Ménéa, located south of Ghardaïa, which contains several varieties of date palms. It spreads over 60 ha (30³8'13.68 "N; 2 59' 37.44 "E) (Figure1). 
The region of Adrar, more precisely Timimoun, hosts two sites: (i) The city of Timimoun, represented by the public gardens of 15 ha $\left(29^{\circ} 15^{\prime} 16.38^{\prime \prime} \mathrm{N} ; 0^{\circ} 14^{\prime} 2.99^{\prime \prime} \mathrm{E}\right)$. This site is characterized by the presence of large trees such as Tamarix aphylla, Casuarina equisetifolia and Eucalyptus sp. (ii) The ancient palm grove of 12 ha $\left(29^{\circ} 15^{\prime} 43.74\right.$ "N; $0^{\circ} 13^{\prime} 6.51$ "E), is characterized by three types of tiered cultivation namely date palm, arboriculture and market gardening (Figure 1).

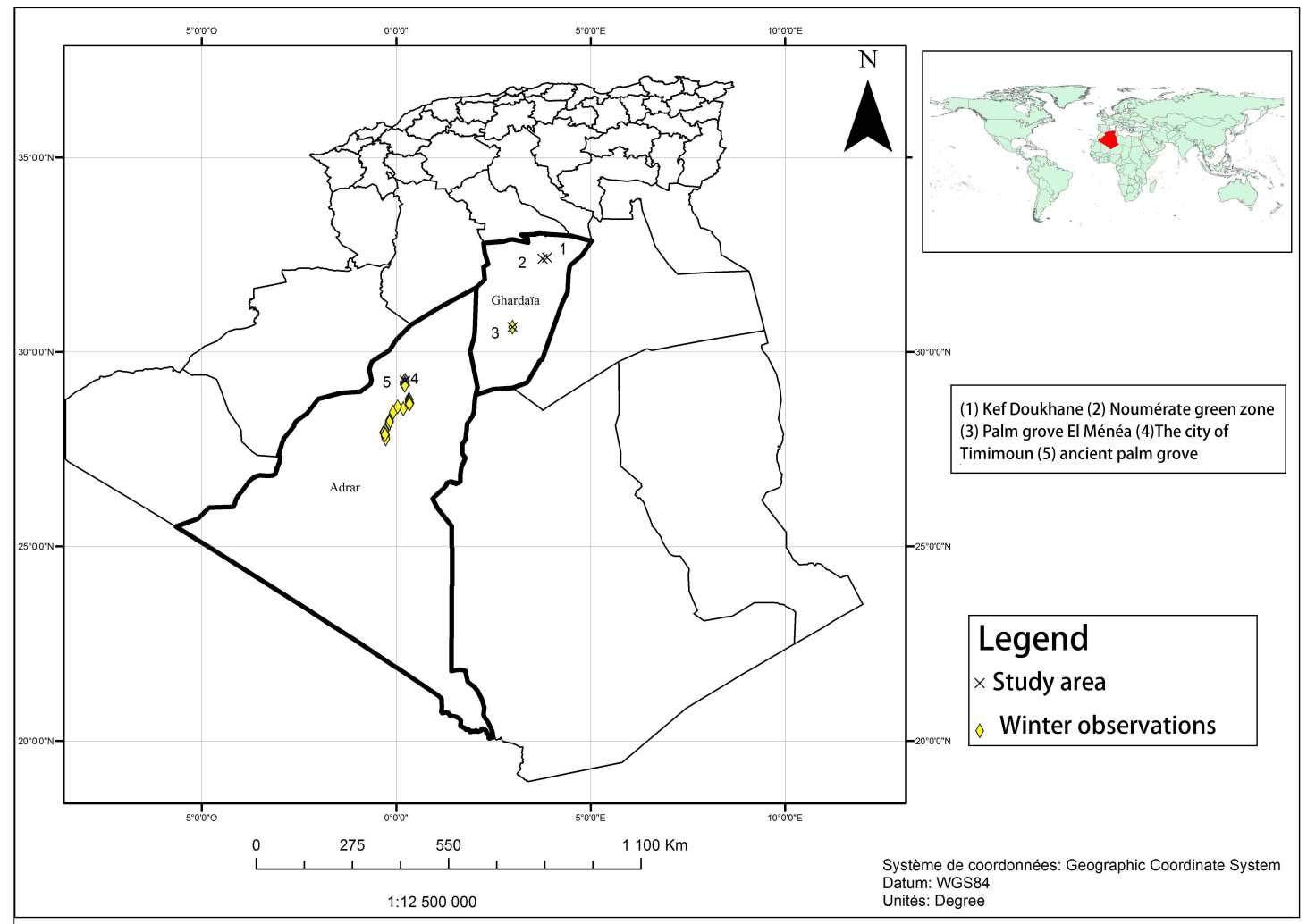

Figure 1. Location map of study areas and winter observation sites

Two methods were used to monitor the Streptopelia turtur population: the Ponctual Index of Abundance (PIA) and the Progressive Sampling Frequency (EFP). The PIA method was implemented during the breeding period in Ghardaïa and Adrar regions. It is represented by two partial PIA, each consisting of 15-unit PIA. The PFS method was used in Timimoun and Adrar, during nonbreeding season (Blondel et al., 1970 and Blondel, 1975).

\section{RESULTS}

In Ghardaïa, the range of the Streptopelia turtur during the breeding season extends throughout the territory, from north to south, especially in palm groves, yards, gardens and around bodies of water, but with a difference in its distribution. The first station (Kef Doukhane wetland) hosted $0.04 \mathrm{c} / \mathrm{ha}$ in 2018 and $0.03 \mathrm{c} /$ ha in 2019. The second zone '(Noumérate green zone) hosted $0.04 \mathrm{c}$. /ha in 2018 and 0.1 couples / hectare in 2019. On the other hand, the third zone (El Ménéa palm grove) hosted $4.5 \mathrm{c}$. /ha in 2018 and 3.45 c. /ha in 2019 (Table 1). 
Current Trends in Natural Sciences

Vol. 9, Issue 17, pp. 65-73, 2020

https://doi.org/10.47068/ctns.2020.v9i17.007

Current Trends in Natural Sciences (on-line)

ISSN: 2284-953X

ISSN-L: 2284-9521
Current Trends in Natural Sciences (CD-Rom) ISSN: 2284-9521 ISSN-L: 2284-9521

Table 1. Density of Streptopelia turtur in Ghardaïa and Timimoun

\begin{tabular}{|l|c|c|c|c|}
\hline \multirow{2}{*}{\multicolumn{1}{|c|}{ Study areas }} & \multicolumn{3}{c|}{ Reproduction (Couples/ha) } & Wintering (Couples/ha) \\
\cline { 2 - 5 } & 2018 & 2019 & 2020 & $2019 / 2020$ \\
\hline Kef Doukhane & 0.04 & 0.03 & - & - \\
\hline Noumérate green zone & 0.04 & 0.1 & - & - \\
\hline El Ménéa new palm grove & 4.5 & 3.45 & - & - \\
\hline Timimoun city & - & 3 & 6.13 & 10.33 \\
\hline Old Timimoun palm grove & - & 2.5 & 2.25 & 2.8 \\
\hline
\end{tabular}

For the first two stations located in the north, the summering period lasts 7 months from April to October, although individuals were observed in the north at the end of March (2018 and 2019) at the old palm grove of Ghardaïa, Metlili, El Atteuf... On the other hand, in the palm grove of El Ménéa, the summering period lasts 8 months from March to October, which confirms that the species is is summer-migrant breeder in the region of Ghardaïa. A single winter observation of a young Streptopelia turtur was recorded on 11 November 2017 in the El Ménéa palm grove (Figure 2D).

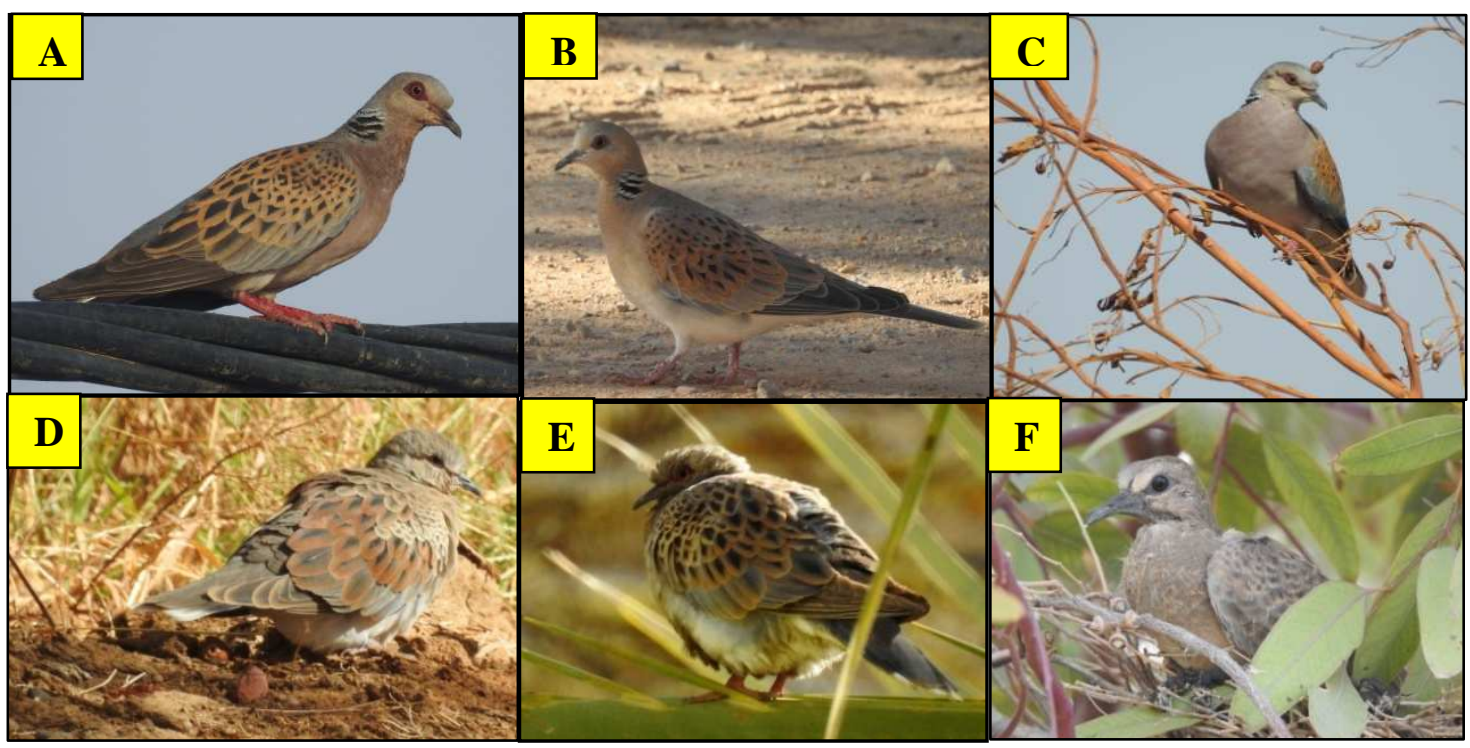

Figure 2. European Turtle Dove (Streptopelia turtur)

A - Noumérate Green Zone, Ghardaïa, Algeria 15/07/2018 @ A. Chedad

$B$ - Timimoun, Adrar, Algeria 04/12/2019 @ A. Chedad

C - Kef Doukhane wetland, Ghardaïa Algeria 23/05/2018 @ A. Chedad

D - Palm grove at El Ménéa Ghardaïa, Algeria 11/11/2017 @ A. Chedad

E - Palm grove at Zarsin, Kébili (South Tunisia), 26/01/2018 @ A. Chedad

F - Noumérate Green Strip, Ghardaïa, Algeria 26/07/2018 @ A. Chedad

In Timimoun during the breeding season, the first station (the city of Timimoun) hosted 3 and 6.13 c. /ha respectively in 2019 and 2020. At the second station (old Timimoun palm grove) the number of recorded pairs was almost similar with $2.5 \mathrm{c}$./ha in 2019 and $2.25 \mathrm{c}$./ha in early 2020 . On the other hand, in wintering period, the first station hosted 10.33 c./ha (2019/2020) and the second 
station hosted only 2.33 c./ha (2019/2020). Thus, the species is considered as resident breeder in the Timimoun region, and in Aougrout, Ouled Mahmoud, Kabertene, Sbaa, Mraguen, administrative center of Adrar, Ouled Ahmed Timmi, Ouled Brahim and Tamentit.

As regards to other winter observations in other regions, only one Streptopelia turtur was recorded on 26 January 2018, in Algeria's neighboring country, Tunisia. Streptopelia turtur was observed in a palm grove in Zarsin, Government of Kebili (Southern Tunisia) (Figure 2E).

In Ghardaiia, the Streptopelia turtur begins to breed in the three study sites just after the prenuptial return, in late March for the southern regions and in early April for the rest of the region. In Timimoun and Adrar, breeding is early, with courtship and nest building beginning in late January and brooding begins in the first week of February.

A total of four nests in brooding were recorded of which two nests were installed on two Leucaena leucocephala trees at a height of 5.5 and $5 \mathrm{~m}$. The third nest was built on Eucalyptus sp. at $6 \mathrm{~m}$ height and the fourth nest installed on Acacia mimosa at $2.5 \mathrm{~m}$ height (Figure 3).

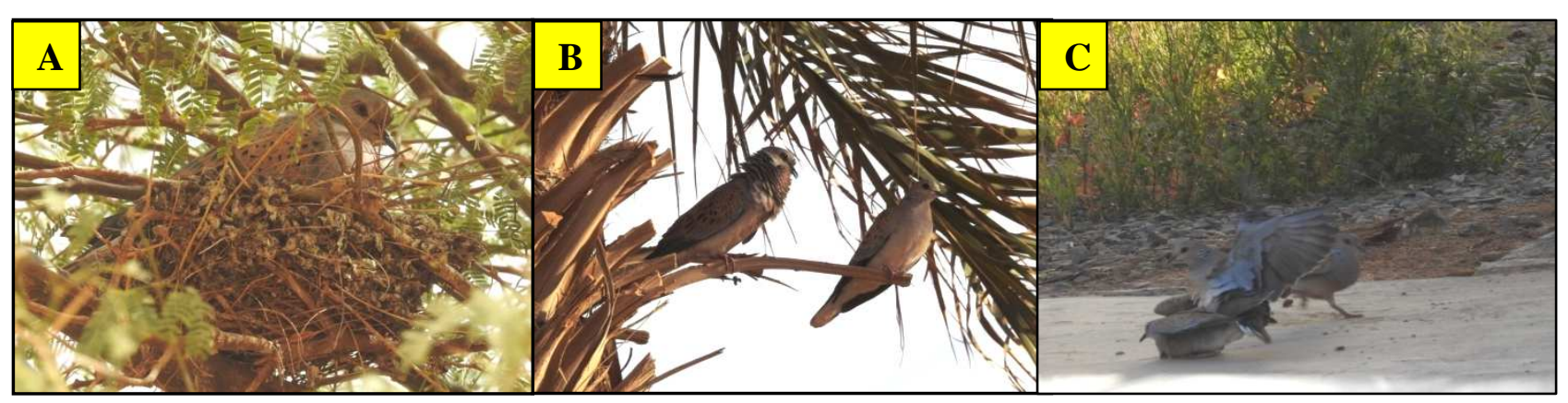

Figure 3. The European Turtle Dove (Streptopelia turtur) observed during the early breeding period A - European Turtle Dove during incubation on the Leucaena leucocephala tree on 08/02/2020 @ A. Chedad $B$ - Wedding parade in Timimoun, Algeria on 10/2/2020 @ A. Chedad C - European turtle dove mating in Timimoun, Algeria on 10/2/2020@ A. Chedad

\section{DISCUSSIONS}

The quantitative study of the population of the Streptopelia turtur in the region of Ghardaiia and Timimoun in several stations highlights the presence of this species during the breeding season in the whole province, but with preferences during distribution. By comparing the same station between years, a slight difference in the number of pairs between years is observed, but this does not apply to the station in the city of Timimoun, where the number of Streptopelia turtur in 2020 doubled compared to 2019.

On the other hand, when comparing the stations among them, a large difference is observed especially in the city of Timimoun $(6.13 \mathrm{c}$./ha) in 2020, and the new palm grove of El Ménéa (4.5 and 3.45 c./ha) in 2018 and 2019 respectively. Data on the density of Streptopelia turtur during the breeding period in Algeria has been documented so far in: (i) Ouargla (southeast), precisely in the palm groves of Mekhadma and Hassi Ben Abdellah; the density is sequentially equal to 2.7 and $0.46 \mathrm{c}$./ha (Ababsa et al., 2013); (ii) Tlemcen (north-east), in the olive orchards between 2007 and 2009; in Bouhassoun and Beaudouin, the average density equals 0.29 and $0.51 \mathrm{c} . /$ ha respectively (Mestari et al., 2013); (iii) Boumerdes (north), the average density in agricultural land in 2006/ 2007 
was 0.79 c./ha (Yahiaoui et al,. 2014 (loc. cit.)); (iv) Djelfa (central Algeria) in the Aleppo pine and holm oak steppe; the density is equal to $0.07 \mathrm{c}$./ha (Souttou et al. 2018).

According to the results, the number of pairs of Streptopelia turtur per hectare varies from one region to another. The density of the species increases in dense environments and where the human presence is low, such as palm groves and oases. Its density remains low in open and urban environments such as orchards and gardens. The presence of food, water, calm, stable and suitable nesting sites directly influences the distribution of the Streptopelia turtur (A. Chedad, pers. com.). Thévenot (1991) mentioned in his study other factors that are associated with urbanization such as road development, buildings, pavement, human population density and mechanical agricultural activities such as ploughing, irrigation and phytosanitary treatment.

The dates of return of the Streptopelia turtur were recorded in 2018 and 2019 in the South of Ghardaïa (El Ménéa and Hassi El F'hel) from the third week of March and in North Ghardaïa (Kef Doukhane, Noumérate) from the first week of April and sometimes a few individuals were observed at the end of March in North Ghardaïa. On the contrary, bird migration dates were recorded throughout the region as early as the last week of October, i.e. the summering period in Ghardaïa usually lasts between 7 and 8 months. In Morocco, the neighboring country, in general, the date of return of the Streptopelia turtur is 24 March \pm 16 days (Thévenot and Beaubrun, 1983).

In Timimoun, during the wintering period, an important number of Streptopelia turtur individuals was recorded in the city ( $10.33 \mathrm{c}$. /ha) in $2019 / 2020$. The species partially leaves the palm groves and oases and prefers to winter in the cities around the gardens by frequenting restaurants and public markets in search of food sources.

Other winter observations in Aougrout, Ouled Mahmoud, Kabertene, Sbaa, Mraguen, administrative center of Adrar, Ouled Ahmed Timmi, Ouled Brahim, Tamentit confirm the wintering and sedentary of the Streptopelia turtur in the whole region, which attributes the status of a resident breeder species. This is probably true also for the South Adrar, Tindouf and Bechar regions.

As mentioned above, there are four subspecies identified for Streptopelia turtur: $S$. $t$. turtur, $S$. $t$. rufescens or isabellina, S. t. hoggara and S. t. arenicola (Cramp, 1985 (loc. cit.); Morel, 1985; (loc. cit.); Veiga, 1998) (loc. cit.). Two subspecies are considered as quasi-sedentary such as $S$. $t$. rufescens (isabellina) and S. t. hoggara (Ash, 1977 (loc. cit.); Gonnisen, 1986 (loc. cit.); Rouxel, 2000 (loc. cit.); Boutin, 2001 (loc. cit.)) and two migratory subspecies S. t. turtur and S. $t$. arenicola.

The subspecies S. t. hoggara breeds in the Hoggar, Tibesti, Tassili and possibly in Timimoun (Heim de Balsac and Mayaud, 1962a (loc. cit.); Heinzel et al., 1985 (loc. cit.); Isenmann and Moali, 2000 (loc. cit.); Boukhemza et al., 2008 (loc. cit.)). As for the subspecies $S$. t. arenicola, it can be observed in the Balearic Islands, from north-western Africa to eastern Cyrenaica in Libya and in the area between the eastern coast of the Caspian Sea and western Atlai, Sin-Kiang and Iran (Veiga, 1998) (loc. cit.).

The Streptopelia turtur that winters in tropical Africa (Cuisin, 2000) and Senegal receives the largest share of the population of western Europe (Boutin, 2000). Probably S. $t$. arenicola nests in the region of Ghardaïa and Timimoun and $S$. $t$. hoggara nests and winters in the region of Timimoun and Adrar.

As for the two winter observations, one in the El Ménéa palm grove (Algeria), on 11 November 2017 and the other in Zarsin, Kébili government (southern Tunisia), on 28 January 2018, they are 
probably lost individuals, found alone in good health, along with Streptopelia senegalensis and Streptopelia decaocto.

Breeding of the Streptopelia turtur in Ghardaiia begins just after the prenuptial return, in late March for the southern regions and in early April for the rest of the study areas. Brahmia et al. (2015) (loc. cit.) noted that the nesting of the Streptopelia turtur in the Guelma region (north-eastern Algeria) is occurring from the beginning of March with the first egg laid on 10 March 2013. Boukhemza et al. (2008) observed that the first egg laying varies between late April and early May.

In general, the dates of the beginning of reproduction are influenced by the date of arrival of the species (Hanane and Baamal, 2011). Contrary to the Timimoun region, the breeding of the Streptopelia turtur is early where the parade starts at the end of January and brooding begins in February. The same is true for the Streptopelia decaocto. Kafi et al. (2015b) noted that in Guelma region, the laying date varies between years, with the first laying observed on 18 February in 2012, and 3 January in 2013.

In the study area, the Streptopelia turtur nests on low-density trees (Leucaena leucocephala, Eucalyptus sp., Acacia mimosa) of medium to high height $(2.5$ and $6 \mathrm{~m})$. The same observation was also made by Hammani et al. (2007) in a Ziban farm; the height of nests chosen by the Streptopelia turtur varies between 2.5 and $6 \mathrm{~m}$. Absi et al. (2015) (loc. cit.) in an oasis in Biskra, noted that the mean height is $5.28 \pm 1.15 \mathrm{~m}$. In addition, Brahmia et al. (2015) (loc. cit.) mentioned it as $4.21 \pm$ $0.08 \mathrm{~m}$.

\section{CONCLUSIONS}

Despite the vast geographical territory occupied by the Streptopelia turtur from the north to the south of Algeria, the number of individuals is still poorly known, and studies on the bio-ecology of the species remain scarce. The data obtained until today are considered as a preliminary study on the distribution and quantification of the numbers of Streptopelia turtur individuals in the northern Sahara and on the delimitation of the area of new wintering sites in Algeria, particularly in Timimoun and Adrar.

With regard to future work, monthly monitoring of the species is envisaged to confirm its occasional wintering or sedentarization in the southern regions of the Northern Sahara, and to identify genetically the migratory and sedentary subspecies of the Streptopelia turtur.

\section{ACKNOWLEDGEMENTS}

This work is part of the preparation of a doctoral thesis in biological sciences, registered at Kasdi Merbah University, Ouargla (Algeria). We would first like to thank the authorities of the Directorate General of Forests (Forest Conservation, Ghardaïa) for facilitating our work in the field. We also thank the farmers in the region who have given us access to their palm groves. Finally, we would like to thank the members of the National Network of Algerian Ornithologists "RNOOA", in particular the Ghardaïa Group. As well as the members of the association "Friends of Birds" (AAO) from Tunisia, for their support and accompaniment.

\section{REFERENCES}

Ababsa, L., Sekour, M., Souttou, K., Guezoul, O., Doumandji, S. (2013). Quelques aspects sur l'avifaune dans deux palmeraies du Sahara Septentrional (Algérie) [Some aspects of avifauna in two palm groves of the Northern Sahara (Algeria)]. Algerian journal of arid environment, 3(1), 59-67."

Absi, K., Belhamra, M., Farhi, Y., Halisa, Y. (2015). Comparison of the reproduction of Collared doves Streptopelia decaocto and Turtle doves Streptopelia turtur in the Ziban Oases (Biskra, Algeria). Journal of Entomology and Zoology Studie, 3 (2), 286-289.

Ash, J.S. (1977). Turtle Dove migration in southern Europe, the Middle East and North Africa. Brit. Bird, 70, 504-506. 


\section{Current Trends in Natural Sciences}

Vol. 9, Issue 17, pp. 65-73, 2020

https://doi.org/10.47068/ctns.2020.v9i17.007

Current Trends in Natural Sciences (on-line)

ISSN: 2284-953X

Current Trends in Natural Sciences (CD-Rom)

ISSN: 2284-9521

ISSN-L: 2284-9521

ISSN-L: 2284-9521

Belabed, A., Draidi, K., Djemadi, I., Zediri, H., Eraud, C., Bouslama, Z. (2012). Deux nouvelles espèces de tourterelles nicheuses Streptopelia turtur arenicola et Streptopelia senegalensis phoenicophila dans la ville d'Annaba (Nordest algérien) [Two new species of nesting doves Streptopelia turtur arenicola and Streptopelia senegalensis phoenicophila in the city of Annaba (north-eastern Algeria)]. Alauda, 80, 299-300.

Blondel, J., Ferry, C. Frochot, B. (1970). La méthode des I.P.A. ou des relevés d'avifaunes par « station d'écoute »[The PIA method or bird surveys by «listening station »]. Alauda, 39 (1), 55-71.

Blondel, J. (1975). L'analyse des peuplements d'oiseaux - éléments d'un diagnostic écologique. La méthode des échantillonnages fréquentiels progressifs (E.F.P) [Analysis of bird populations elements of an ecological diagnosis. The Progressive Sampling Frequency method (EFP)]. Rev. écol. (Terre et Vie), 29 (4), $533-589$.

Boukhemza, N.Z., Belhamra, M., Boukhemza, M., Doumandji, S., Voisin, J.F. (2008). Biologie de reproduction de la Tourterelle des bois streptopelia turtur arenicola dans le Nord de l'Algérie [Reproductive biology of the European Turtle Dove Streptopelia turtur arenicola in the North of Algeria]. Alauda, 76 (3), 207-222.

Boutin, J.M. (2000). Elements for a Turtle Dove (Streptopelia turtur) management plan. Game and Wildifel, 18, 87112

Boutin, J.M. (2001). Les populations de Colombidés en France In: Actes du colloque international «Suivi de population de Columbidés » [Populations of Colombidae in France In:vProceedings of the international conferencev «Columbidae population monitoring»] Bordeaux 17-18 Décembre 1998, (J.) Veiga, Coord., Faune sauvage, 36, 26-32.

Brahmia, H., Zeraoula, A., Bensouilah, T., Bouslama, Z. Houhamdi, M. (2015). Breeding biology of sympatric Laughing Streptopelia senegalensis and Turtle Dove Streptopelia turtur: a comparative study in north east Algeria. Zoology and Ecology, 25 (3), 220-226.

Brahmia, H. (2015) - Ecologie de la reproduction de la Tourterelle maillée Streptopelia senegalensis dans la région de Guelma Nord-Est de l'Algérie [Reproductive ecology of the laughing dove Streptopelia senegalensis in the area from Guelma North-East of Algeria]. Thèse de Doctorat, Université Badji Mokhtar, Annaba.

Chehma, A. (2006). Catalogue des plantes spontanées du Sahara septentrional Algériens [Catalog of spontaneous plants of the Algerian northern Sahara]. (Vol. 1, 140 p .) Laboratoire, Ecol., Syst., Univ. Ouargla.

Cramp, S. (1985). The Birds of the Western Palearctic, (Vol. IV., 960 p) Oxford, New York. Oxford University Press.

Cuisin, M., Doppia, D. (1992). Encyclopédie des oiseaux "Encyclopedia of birds " (pp. 429-259). Ed. Grund, Paris.

Cuisin, M. 2000. Oiseaux des jardins et des forêts [Birds of gardens and forests] (pp.183). Ed Delachaux \& Niestle, Paris.

Doumandji, S., Doumandji-Mitiche, B. (1994). Ornithologie appliquée à l'agronomie et à la sylviculture [Ornithology applied to agronomy and forestry] (pp.124). Ed. Off. Pub. Univ. Alger.

Gonnisen, L. (1986). Oiseaux semblables : les tourterelles [Similar birds: doves]. Le monde des oiseaux, 2, 80.

Hammani, F., Chabbi, Y., Djellab, K. (2007). La situation éco-biologique de population de la Tourterelle des bois (Streptopelia turtur) en phase de cycles de reproduction dans trois stations : Zeralda, Zibans et Illisi.[The eco biological situation of the European Turtle Dove population (Streptopelia turtur) in phase of reproduction cycles in three stations: Zeralda, Zibans and Illisi] Thése Ing. Ins. Agri, Universite de Biskra.

Hanane, S., Baamal, L. (2011). Are Moroccan fruit orchards suitable breeding habitats for Turtle Doves Streptopelia turtur? Bird Study, 58 (1), 57-67.

Heim de Balsac, H., Mayaud, N., (1962a). Les oiseaux du Nord-Ouest de l'Afrique [The birds of Northwest Africa] (pp.486) Ed. Paul Lechevalier, Paris.

Heim de Balsac, H., Mayaud, N. (1962b). Contribution à l'Ornithologie du Sahara Central et du Sud Algérien [Contribution to the Ornithology of Central Sahara and South Algeria]. (pp 127) Ed., Imprimerie. Le Typolitho, Alger.

Heinzel, H., Fitter, R., Parslow, J. (1985). Oiseaux d'Europe, d'Afrique du Nord et du Moyen-Orient [Birds from Europe, North Africa and the Middle East]. (pp.319) Ed. Delachaux et Niestlé, Neuchatel, (Suisse).

Isenmann, P., Moali, A. (2000). Oiseaux d'Algérie [Birds of Algeria]. (pp.336) Société d'Etudes Ornithologiques de France, SEOF, Paris.

Kafi, F., Hanane, S., Bensouilah, T., Zeraoula, A., Brahmia, H., Houhamdi, M., (2015a). Les facteurs déterminant le succès de la reproduction des Tourterelles des bois (Streptopelia turtur) dans un milieu agricole nord-africain [Factors determining reproductive success European Turtle Doves (Streptopelia turtur) in a North African farming environment]. Revue d'Ecologie. Terre et Vie, 70 (3), 271-279.

Kafi, F. (2015b). Structure et écologie des Tourterelles nicheuses dans l'extrême Nord-est de l'Algérie [Structure and ecology of nesting Doves in the extreme north-east of Algeria]. Thèse de Doctorat, Univ Guelma, Algérie.

*Corresponding author, E-mail address: chedad.abdelwhab@univ-ouargla.dz / agrochedad@yahoo.fr 


\section{Current Trends in Natural Sciences}

Vol. 9, Issue 17, pp. 65-73, 2020

https://doi.org/10.47068/ctns.2020.v9i17.007

Current Trends in Natural Sciences (on-line)

ISSN: 2284-953X

Current Trends in Natural Sciences (CD-Rom)

ISSN: 2284-9521

ISSN-L: 2284-9521 ISSN-L: 2284-9521

Mediouni, K. (1997). Organisation et potentialités de la diversité biologique Algérienne [Organization and potentialities of Algerian biological diversity]. (Tom II, pp.158) Min. Envi.,Projet Alg. /97 /G31/FEM/PNUD.

Merabet, A., Doumandji, S., Baziz, B. (2010). Expansion des Populations des Colombiformes au sein des Oiseaux des Milieux Agricoles et Suburbains en Mitidja (Algérie). [Expansion of Columbiformes Populations within the Birds of Agricultural and Suburban Environments in Mitidja (Algeria)] European Journal of Scientific Research,43, 113-126.

Mestari, M., Khelil, M. A., Reynaud, P. A., Mesli, L. (2013). Suivi de reproduction des espèces d'oiseaux nichant sur les vergers d'olivier de la wilaya de Tlemcen (Nord-Ouest Algérien) [Reproduction monitoring of bird species nesting in olive orchards in the wilaya of Tlemcen (North-West Algeria)]. Revue Ecologie-Environnement, 9, 16.

Morel, M.Y. (1985). La tourterelle des bois Streptopelia turtur, en Sénégambie : évolution de la population au cours de l'année et identification des races [The European turtle dove, Streptopelia turtur, in Senegambia: evolution of the population during the year and breed identification]. Alauda, 53,100-110.

Rouxel, R. (2000). La tourterelle des bois Streptopelia turtur en Europe Orientale : Synthèse des données bibliographiques [The European turtle dove Streptopelia turtur in Eastern Europe: Summary of bibliographic data]. Bull. Liais. et inf. OMPO, 22, 5-19.

Souttou, K., Ababsa, L., Abidi, F., Guezoul, O., Sekour, M. Doumandji, S. (2018). Composition et structure avifaunistique dans une steppe arborée de Pin d'Alep a chêne vert à sehary guebli (Djelfa, Algérie) [Bird composition and structure in a wooded steppe from Aleppo pine to holm oak to sehary guebli (Djelfa, Algeria)]. Lebanese Science Journal, 19(1),19-30.

Thévenot, M. Beaubrun, P. (1983). Statut et répartition actuelle des Galliformes, Charadriiformes et Columbiformes nicheurs au Maroc [Status and current distribution of Galliformes, Charadriiformes and Columbiformes nesters in Morocco]. Symposium international sur la conservation et la gestion de la Faune sauvage méditerranéenne. Fès, 16-18 mars.

Thévenot, M. (1991). Les oiseaux des forêts de chêne-liège du Maroc. [The birds of the cork oak forests of Morocco] pp 197- 233 in: c. villement \& a. Fraval (eds). La faune du chêne-liège. actes Editions, inst. agro. vét. Hassan ii, rabat.

Veiga, J. (1998). Eléments d'un plan en faveur de la tourterelle des bois (Streptopelia turtur). [Elements of a plan for the European turtle dove (Streptopelia turtur)] Bulletin de liaison et d'information d'O.M.P.O. (oiseaux migrateurs du paléarctique occidental), 17, 7-16.

Yahiaoui, K., Arab, K., Belhamra, M., Browne, S.J., Boutin, J.M. Moali, A. (2014). Habitat occupancy by European Turtle doves (Streptopelia turtur) in the Isser Valley, Algeria. Rev. Écol. (Terre Vie), 69 (3-4), 234-246. 